\title{
Pengembangan Media Laboratorium Virtual untuk Mendukung Pembelajaran Praktikum SMA
}

\author{
Anang Purwoko 3 \\ maspurkopral67@student.uns.ac.id
}

\begin{abstract}
Abstrak: This research aims to: 1) develop a virtual laboratory media as a supporter of the implementation of high school physics practicum; and 2) know the effectiveness of the use of virtual laboratories in high school physics learning. This research uses research and development (R \& D) methods. The procedure for developing virtual laboratory media is carried out through: 1) field studies, literature studies, about the implementation of practicum in physics learning, interviews with teachers, monitoring of school equipment to support the implementation of physics practicum. 2) development: pre-production, production, and post-production, and 3) At this stage what is done is to study the effectiveness of the virtual laboratory media that have been developed on the level of student understanding through performance. The developed virtual laboratory media obtained a score of feasibility by material experts, media experts and students of 4.1 with good categories suitable for use in the learning process. The results of this study indicate: 1) There are significant differences in the pre-test and post-test scores in the experimental class with the sig value. 0,000. 2) There is a significant difference in the value of the post-test in the experimental class and the control class with a significance value of 0.039 . Based on the results of the effectiveness test, it can be concluded that the use of laboratory media in high school physics teaching and learning activities significantly increases learning outcomes that can be used to increase the use of direct equipment.
\end{abstract}

Keyword: Learning Media, Virtual Laboratory, Physics

${ }_{3}^{3}$ Mahasiswa Magister Teknologi Pendidikan Universitas Sebelas Maret Surakarta 


\section{PENDAHULUAN}

$\mathrm{T}$ eknologi dalam pembelajaran sudah tidak asing lagi di kalangan para pendidik, baik pendidikan formal maupun non formal. Komputer sudah menjadi bagian dalam pelaksanaan pembelajaran di Indonesia. Tahun 2017 Indonesia menerapkan Ujian Nasional Berbasis Komputer. Hal ini menjadi bukti bahwa pendidikan di Indonesia tidak pernah lepas dari perkembangan teknologi. Teknologi dalam pembelajaran bisa berfungsi sebagai media ajar, bahan ajar, bahkan menjadi sumber pembelajaran serta alat evaluasi pembelajaran. Hal ini didukung dengan adanya berbagai kemampuan dalam komputer seperti aplikasi pembelajaran, video pembelajaran, dan jaringan internet.

Berbagai macam pendekatan instruksional yang dikemas dalam bentuk program pengajaran dengan media komputer atau CAI (Computer-Assisted Instruction) seperti: video tutorial, simulasi, drill dan practice bisa diperoleh melalui perangkat computer. Namun dari hasil observasi yang dilakukan, penggunaan komputer dalam pembelajaran masih sebatas sebagai pengganti papan tulis atau untuk menampilkan video saja.

Pembelajaran pada siswa seharusnya menggunakan pendekatan student-centered. Teknologi seharusnya tidak hanya digunakan sebagai perangkat untuk demonstrasi dan electronic overhead projector saja, akan tetapi bisa menjadi bagian dari pelaksanaan pembelajaran (UNESCO, 2002, Serdyukov, 2017). Dalam pendekatan student-centered, siswa menjadi sumber masalah yang diselidiki. Siswa dan guru harus memiliki kesempatan menarik kesimpulan, dan menyampaikan hasil menggunakan alat elektronik untuk menyelesaikan tugas ini. Oleh karena itu lingkungan pembelajaran hendaknya dapat mendorong siswa untuk dapat aktif mencari tahu melalui kegiatan diskusi, observasi dan praktikum.

Kegiatan praktikum memberikan pengalaman langsung terhadap siswa dalam pembelajaran fisika serta meningkatkan keterampilan siswa dalam menggunakan peralatan, pemecahan permasalahan dan berpikir logis (Usmeldi, 2016). Pembelajaran praktik merupakan pembelajaran yang memberikan pengalaman langsung terhadap peserta didik. Praktik membuat peserta didik dapat berperan sebagai pelaku dalam pembelajaran sehingga meningkatkan daya ingat dan pemahaman peserta didik. Hal ini sesuai dengan kerucut pengalaman yang dijelaskan oleh Edgar Dale (Sprawls, 2008). Dale memberikan penjelasan dalam kerucut pengalaman bahwa melakukan simulasi dan melakukan praktik langsung dapat memberikan pengalaman yang dapat diingat dengan baik oleh peserta didik.

Pembelajaran praktikum yang dilakukan pada proses pembelajaran di Indonesia masih terbilang kurang. Fisika tidak hanya merupakan kumpulan dari teori saja, namun juga implementasi dari teori tersebut, sehingga dalam pembelajaran siswa perlu melakukan praktikum sebagai implementasi dari pelajaran abstrak yang diterapkan dalam kondisi yang nyata. Beberapa kendala dalam pelaksanaan praktikum yang terjadi di sekolah adalah alat dan perlengkapan yang kurang memadai dalam melakukan praktikum. Dari hasil observasi, bahkan masih ada di beberapa sekolah yang belum memiliki laboratorium fisika. Kondisi ini sangat perlu diperhatikan mengingat sarana dan prasarana di sekolah untuk melakukan praktikum dapat membantu pemahaman siswa pada mata pelajaran fisika. Penyebab dari kurangnya peralatan praktikum yang ada di beberapa sekolah adalah mahalnya dana yang dibutuhkan untuk pengadaan peralatan yang digunakan untuk praktikum. Hal ini yang menjadikan beberapa sekolah swasta belum dapat memberikan sarana dan prasarana praktikum yang memadai bagi para siswanya. Kurangnya peralatan yang memadai dalam laboratorium dan kurangnya pelaksanaan praktikum mengakibatkan ketidak mampuan siswa untuk mengeksplorasi beragam bidang fisika. Hal ini juga mengakibatkan kurangnya motivasi belajar fisika. Lain halnya dengan siswa yang memiliki pengalaman praktikum cenderung memiliki keterampilan dan kepercayaan diri yang baik daripada siswa yang memiliki pengalaman praktikum terbatas (Ifeanyi, 2012).

Alternatif solusi untuk pengajaran fisika melalui praktikum secara mudah, murah dan menyenangkan bagi siswa yaitu pembelajaran praktikum menggunakan bantuan media virtual laboratory. 
Melalui laboratorium virtual, simulasi suatu kondisi yang kompleks, terlalu mahal atau berbahaya, yang kadang tidak dapat dilakukan pada kondisi nyata, menjadi dapat dilakukan. Secara finansial, membangun sebuah laboratorium virtual juga relatif sangat terjangkau. Laboratorium berbasis komputer ini memungkinkan para siswa atau mahasiswa dapat melakukan praktikum atau eksperimen seolah-olah menghadapi fenomena atau set peralatan laboratorium nyata (Nirwana, 2011). Penggunaan laboratorium virtual dapat meningkatkan kognitif, afektif dan psikomotorik secara simultan (Jaya, 2012).

Berdasarkan uraian tersebut untuk mempermudah proses pembelajaran yang menggunakan pendekatan student-centered dan pelaksanaan praktikum, perlu dikembangkan laboratorium virtual. Laboratorium virtual juga harus murah dan mudah untuk digunakan sehingga dapat digunakan secara efektif pada mata pelajaran fisika. Pembelajaran adalah sesuatu kerangka konseptual yang menggambarkan bagaimana pengetahuan diserap, diproses dan dipertahankan selama pembelajaran. Dalam pembelajaran pengaruh kognitif, emosional dan lingkungan serta pengalaman sebelumnya saling berperan dalam bagaimana pemahaman tentang ilmu pengetahuan diperoleh dan dipertahankan (Simandan, 2013). Belajar merupakan proses interaksi mental antara individu dan materi dan lingkunganya yang terjadi pada individu dan dapat menyebabkan perubahan atau hasil usaha belajar (Illeris, 2017). Belajar merupakan proses yang fundamental dalam proses pendidikan. Belajar merupakan kegiatan yang pokok dan penting dalam setiap proses pendidikan. Perubahan tingkah laku maupun bertambahnya pengetahuan peserta didik menjadi hasil yang diperoleh dari proses belajar.

Pembelajaran yang efektif membutuhkan banyak kemampuan untuk melakukan proses elemen belajar (Robotham, 2003). Pembelajaran adalah suatu proses interaksi yang tersusun meliputi unsurunsur manusiawi, fasilitas, perlengkapan, dan prosedur yang saling memengaruhi untuk mencapai tujuan dari pembelajaran. Sebagai sebuah proses, keseluruhan dari unsur pembelajaran harus saling berinteraksi dan terkait. Keseluruhan unsur tersebut memberikan pengaruhnya masing-masing terhadap tujuan pembelajaran.

Proses pembelajaran terdiri dari tahapan perencanaan, tahap pelaksanaan dan evaluasi. Perencanaan pembelajaran disusun berdasarkan kebutuhan dan tujuan pembelajaran atau hasil yang akan dicapai. Pelaksanaan pembelajaran merupakan implementasi atau penerapan dari desain yang telah dirancang oleh pengajar. Hakikat dari pelaksanaan belajar merupakan kegiatan operasional pembelajaran itu sendiri. Pada tahap ini pengajar menerapkan metode, teknik dan strategi pembelajaran serta pemanfaatan berbagai media yang menunjang dalam pembelajaran. Pada tahap evaluasi merupakan mekanisme untuk mengukur perubahan perilaku yang telah terjadi atau pengetahuan yang dimiliki peserta didik.

Proses interaksi belajar mengajar selalu memiliki sejumlah unsur yang bisa disebut sebagai komponen pembelajaran. Sebagai sebuah sistem, seluruh komponen pembelajaran tersebut membentuk integritas atau satu kesatuan yang utuh. Masing-masing komponen satu saling berinteraksi dan berhubungan secara aktif untuk mencapai tujuan pembelajaran (Hamalik, 2005). Pembelajaran memiliki beberapa faktor yang harus diperhatikan meliputi faktor manusia (pengajar dan peserta didik), faktor tujuan belajar, faktor bahan ajar, faktor metode pembelajaran faktor sarana serta alat bantu pembelajaran, dan evaluasi pembelajaran. (Sudjana, 2007; Hamalik, 2005). Keseluruhan faktor tersebut saling berkaitan dan berpengaruh untuk mencapai tujuan pembelajaran. Faktor-faktor tersebut adalah tujuan pembelajaran, materi pembelajaran, metode pembelajaran, sarana pembelajaran dan evaluasi.

Tujuan pembelajaran merupakan hasil dari pelaksanaan proses pembelajaran (Gagne \& Briggs, 1974). Tujuan pembelajaran merupakan komponen terpenting dalam proses pemelajaran. Tujuan pembelajaran berfungsi sebagai tolok ukur ketercapaian proses belajar. Tujuan pembelajaran merupakan rumusan tingkah laku dan kemampuan yang harus dicapai dan dimiliki oleh peserta didik setelah melakukan proses belajar. Tujuan pembelajaran ini dapat bersifat kognitif, afektif, maupun psikomotorik 
Sarana pembelajaran berperan menunjang jalanya pembelajaran. Pemberian sarana yang baik seperti ruangan dan peralatan yang memadai dapat membantu siswa untuk mencapai tujuan pembelajaran (Karna \& Julin, 2015; Mulyasa, 2003). Secara umum sarana pembelajaran dikelompokan menjadi 3 kelompok besar yaitu bangunan, alat pelajaran seperti alat peraga dan laboratorium, dan media pembelajaran. Evaluasi pembelajaran meliputi pengukuran dan penilaian. Pengukuran berkaitan dengan ukuran kuantitatif, sedangkan penilaian terkait dengan kualitas (Arikunto, 2006). Pelaksanaan evaluasi pembelajaran memiliki tujuan untuk dapat melihat hasil dari pelaksanaan proses pembelajaran. Sukses atau tidaknya pembelajaran dapat dilihat dari hasil evaluasi pembelajaran. Proses pelaksanaan evaluasi pembelajaran dilakukan terhadap siswasebagai bukti ketercapaian pelaksanaan pembelajaran terhadap tujuan pembelajaran.

Belajar Fisika pada hakikatnya merupakan cara ideal untuk memperoleh kompetensi yang berupa keterampilan, memelihara sikap, dan mengembangkan pemahaman konsep yang berkaitan dengan pengalaman sehari-hari. Keterampilan, sikap dan konsep ini tidak dapat dipisahkan satu dengan yang lainnya. Belajar fisika ini pada dasarnya bertujuan untuk menguasai produk yang berupa kumpulan hukum, teori, prinsip, aturan, dan rumus-rumus yang terbangun oleh konsep-konsep sesuai proses pengkajiannya. Adapun produk sains terutama fisika merupakan kumpulan pengetahuan yang berupa fakta, konsep, prinsip, hukum, dan teori mengenai gejala alam. Pembelajaran fisika yang dilakukan di sekolah pada tingkat SMA dan sederajat hendaknya mengacu pada Peraturan Menteri Pendidikan dan Kebudayaan (PERMENDIKBUD) nomor 24 tahun 2016 tentang kompetensi inti dan kompetensi dasar. Dalam PERMENDIKBUD dijelaskan tentang kompetensi pembelajaran fisika yang harus dikuasai, pada jenjang SMA (Kemendikbud, 2016). Kompetensi yang harus dimiliki peserta didik dalam pembelajaran fisika pada jenjang SMA terbagi atas 4 kompetensi inti yaitu (1) kompetensi sikap spiritual , (2) sikap sosial, (3) pengetahuan, dan (4) keterampilan. Pembelajaran Fisika pada hakikatnya merupakan pembelajaran yang lebih menekankan kepada fisika sebagai produk, sebagai proses dan sebagai sikap. Fisika sebagai produk merupakan kumpulan pengetahuan yang berupa fakta, konsep, prinsip, hukum, dan teori mengenai gejala alam. Dengan penguasaan fisika, siswa diharapkan dapat mengerti dan mengaplikasikan sains untuk tujuan pemecahan masalah dan pengembangan ilmu pengetahuan dan teknologi.

Praktikum merupakan bagian penting dalam pembelajaran fisika (Mhlongo, Kriek, \& Basson, 2011). Metode praktikum merupakan suatu cara penyajian materi pelajaran dengan cara siswa melakukan percobaan dengan mengalami untuk membuktikan sendiri sesuatu pertanyaan atau hipotesis yang dipelajari. Siswa melakukan suatu percobaan tentang suatu hal, mengamati prosesnya serta menyimpulkan hasil suatu percobaan kemudian hasil pengamatan itu disampaikan di kelas dan dievaluasikan guru. Hubungan natara teori dan praktik adalah symbiotic, teori meberikan kontribusi kepada praktik dan praktik memberikan kontribusi pada pemahaman teori (Hartley, 2008)

Metode praktikum adalah proses pembelajaran yang memposisikan peserta didik melakukan dan mengalami sendiri, mengikuti proses, mengamati obyek, menganalisis, membuktikan dan menarik kesimpulan suatu obyek, keadaan dan proses dari materi yang dipelajari tentang gejala alam dan interaksinya (Djamarah \& Bahri 2002). Hal ini akan dapat membuat perspektif peserta didik berubah dari hal yang abstrak kedalam real perspective. Persepsi peserta didik tentang materi pembelajaran dapat mempengaruhi kualitas hasil belajar (Sambrook, 2001). Praktikum dapat dilakukan pada suatu laboratorium atau diluar laboratorium, pekerjaan praktikum mengandung makna belajar untuk berbuat, karena itu dapat dimasukkan dalam metode pembelajaran. Berdasarkan jumlah pesertanya praktikum dibedakan menjadi praktikum individual, praktikum beregu (berkelompok) dan demonstrasi. Berdasarkan segi pengendalianya praktikum dibagi menjadi dua kategori, yaitu praktikum mandiri dan praktikum terkendali.

Praktikum dalam pembelajaran fisika digunakan untuk mengaplikasikan konsep dan teori yang telah dipelajari peserta didik (Mishra, Vijayshri \& Garg, 2010). Pelaksanaan praktikum dalam kegiatan 
pembelajaran fisika tidak hanya meningkatkan pemahaman siswa terhadap materi dan konsep yang telah dipelajari oleh peserta didik. Kegiatan ini juga dapat meningkatkan keterampilan, motivasi dan rasa percaya diri siswa.

Media pembelajaran bahan, alat atau peristiwa yang dapat menciptakan kondisi yang memungkinkan siswa menerima pengetahuan (Anitah, 2008). Definisi yang lainnya mengenai media pembelajaran adalah segala sesuatu yang dapat digunakan untuk menyalurkan pesan dari pengirim ke penerima sehingga merangsang pikiran, perasaan, perhatian dan minat serta kemauan peserta didik sedemikian rupa sehingga proses belajar terjadi dalam rangka mencapai tujuan pembelajaran secara efektif (Sukirman, 2012). Banyak jenis media yang dapat digunakan dalam pembelajaran, salah satunya adalah komputer atau dapat juga disebut CAI (Computer-Assisted Instruction). Penggunaan komputer dalam pembelajaran dapat menyajikan berbagai macam media secara terpadu dan kolaboratif. Penggunaan komputer sebagai media pembelajaran dapat memanfaatkan berbagai aplikasi yang mendukung proses pembelajaran. Komputer sebagai media pembelajaran dapat dikelompokan menurut format penyampaianya yaitu tutorial, drill and practice, simulasi, percobaan atau eksperimen dan permainan (Smaldino, Lowther. \& Russell, 2008). Penggunaan CIA dalam pembelajaran membuat peserta didik memiliki pengetahuan yang lebih baik (Jenny \& Fai, 2001).

Program tutorial merupakan program yang dalam penyampaian materinya dilakukan secara tutorial, sebagaimana layaknya tutorial yang dilakukan oleh guru atau instruktur. Program Drill and practice ini dimaksudkan untuk melatih pengguna sehingga memiliki kemahiran dalam suatu keterampilan atau memperkuat penguasaan suatu konsep. Program simulasi multimedia dengan format CAI mencoba menyamai proses dinamis yang terjadi di dunia nyata, misalnya untuk menyimulasikan pesawat terbang dimana pengguna seolah-olah melakukan aktivitas menerbangkan pesawat terbang, menjalankan usaha kecil, atau pengendalian pembangkit listrik tenaga nuklir dan lain-lain. Format percobaan atau eksperimen ini mirip dengan format simulasi, namun lebih ditujukan pada kegiatan-kegiatan yang bersifat eksperimen, seperti kegiatan praktikum di laboratorium IPA, Biologi atau Kimia. Permainan dengan menggunakan CIA bentuk permainan yang disajikan dengan tetap mengacu pada proses pembelajaran, dan dengan program multimedia berformat ini diharapkan terjadi aktivitas belajar sambil bermain.

Laboratorium virtual atau bisa disebut dengan istilah Virtual Labs adalah serangkaian alat-alat laboratorium yang berbentuk perangkat lunak (software) komputer berbasis multimedia interaktif, yang dioperasikan dengan komputer dan dapat menyimulasikan kegiatan di laboratorium seakan-akan pengguna berada pada laboratorium sebenarnya. Laboratorium virtual interaktif merupakan pendekatan yang sangat baik untuk melatih siswa memahami prinsip-prinsip teknis (Redel-Maciasa et al, 2016). Laboratorium virtual dapat dibedakan menjadi dua tipe utama yaitu laboratorium berdasarkan simulator dan laboratorium yang berbasis pada peralatan hardware yang nyata baik 2-D maupun 3-D. Tipe pertama didasarkan pada set model perangkat lunak yang merupakan objek atau sistem dalam tingkat abstraksi tertentu. Satu-satunya masalah di sini adalah dengan keakuratan perilaku simulator. Sangat sering benda nyata berbeda dari model abstrak mereka. Hal ini karena model abstrak yang dikembangkan menjadi sederhana dan untuk membantu siswa untuk memahami dasar-dasar. Kebanyakan dari peralatan praktikum tidak dapat mewakili semua fungsi dari objek simulasi.

Jenis kedua laboratorium virtual yang mencakup sebagian besar kualitas jenis pertama dan memungkinkan pendekatan ini untuk yang klasik. Di setiap kelas terdapat rak-rak dengan peralatan yang tidak dapat digunakan untuk pembelajaran jarak jauh dan tidak dapat diakses bagi para siswa sepanjang waktu. Jadi menggabungkan klasik dengan belajar yang modern memungkinkan akses remote ke peralatan nyata dapat meningkatkan fleksibilitas proses pengajaran dan penggunaan laboratorium nyata. Menggunakan teknologi perangkat lunak dan jaringan menyediakan akses yang terhubung ke peralatan Akses yang luas di sekolah terhadap teknologi informasi dan kompter membuat pembelajaran di sekolah dapat menerapkan berbagai metode pembelajaran yang interaktif dan menarik bagi peserta didik. Penggunaan media dengan berbasis teknologi komputer bisa diperoleh dengan mudah dan dapat 
diterapkan pada pembelajaran di sekolah untuk menarik perhatian siswa sehingga pembelajaran lebih interaktif. Salah satu media berbasis komputer yang dapt digukan dalam pebelajaran fisika adalah media laboratorium virtual. Penggunaan laboratorium virtual dalam pembelajaran dapat membuat proses pembelajaran lebih menarik, interaktif dan mengurangi penggunaan waktu pembelajaran dibandingkan dengan praktikum secara langsung (Nirwana, 2011).

\section{METODE PENELITIAN}

Jenis penelitian yang digunakan dalam penelitian ini adalah penelitaian pengembangan atau dikenal dengan Research and Development (R\&D). Penelitian pengembangan dimulai dengan kegiatan analisis/research kemudian dilanjutkan dengan kegiatan pengembangan/development. Kegiatan analisis/research meliputi pengumpulan data dan analisis data. Dari hasil analisis tersebut dapat diketahui apa kebutuhkan subjek penelitian. Untuk kegiatan pengembangan (development) kegiatannya meliputi: memproduksi produk atau menyempurnakan produk yang sudah ada. Sebelum menggunakan produk yang sudah dikembangkan atau disempurnakan, terlebih dahulu produk harus divalidasi oleh ahli serta diuji coba efektifitasnya pada skala yang kecil.

Tujuan dari penelitian pengembangan pada pendidikan adalah terciptanya produk baru atau perbaikan dari produk yang sudah ada, untuk meningkatkan tercapainya tujuan pembelajaran secara maksimal dan menjadikan proses pembelajaran menjadi lebih efektif dan efisien. Penelitian ini mempunyai tujuan untuk mengamati, menganalisa dan mendeskripsikan data mengenai proses pembuatan media laboratorium virtual pada mata pelajaran Fisika terutama pada Praktikum Fisika dan efektifitas penggunaan laboratorium virtual dalam proses pembelajaran.

Sebelum mengembangkan media laboratorium virtual ini tahap awal yang dilakukan adalah studi pendahuluan. Kegiatan dalam studi pendahuluan ini berupa menganalisis permasalahan yang dihadaapi dalam proses pembelajaran pada mata pelajaran fisika terkhusus pada pelaksanaan praktikum serta kebutuhan guru dan siswa terhadap media pembelajaran. Teknik pengumpulan data dalam studi pendahuluan yaitu menggunakan obervasi dan wawancara.

Media yang sudah dirancang kemudian divalidasi oleh ahli materi dan ahli media. Tahap validasi dan uji coba tersebut bertujuan untuk memastikan bahwa media yang dikembangkan dapat layak digunakan dan berfungsi dengan baik ketika diimplementasikan pada proses pembelajaran sebenarnya. Ahli ini akan memberikan penilaian pada aspek pembelajaran dan materi yang dikembangkan melalui kuisioner yang telah disiapkan. Penilaian berupa nilai dan saran secara tertulis berdasarkan materi yang telah disusun oleh peneliti. Penilaian untuk aspek materi meliputi 1). Kesesuaian media dengan tujuan pembelajaran, 2). Kesesuaian materi dengan kurikulum, 3). Penyajian materi dalam media pembelajaran, 4). adanya penilaian \& evaluasi dalam media serta 5). Pendekaatan terhadap siswa \& penggunaan dalam proses belajar. Aspek penilaian untuk media meliputi 1). Desain Tampilan (Layout), 2). Desain isi media, 3). Pengelolaan \& Pengembangan media, serta 4). Kemudahan akses penggunaan media. Data yang diperoleh kemudian dijumlahkan dan dicari rerata datanya. Hasil rerata data yang diperoleh tersebut dijadikan penentu kualitas produk media laboratorium virtual yang dikembangan.

Setelah dilakukan validasi dari ahli materi dan ahli media, langkah selanjutnya yang perlu dilakukan adalah melakukan uji model. Tahap ini merupaan tahap uji coba untuk menilai produk berdasarkan penilaian pengguna atau siswa. Uji model dibagi menjadi dua, yaitu uji kelompok kecil dan uji lapangan. Uji coba kelompok kecil bertujuan untuk mengidentifikasi kekurangan-kekurangan produk awal yang telah didesain dan telah dinilai oleh para ahli berdasarkan pandangan siswa. Aspek-aspek yang dinilai pada uji coba kelompok kecil di antaranya meliputi kesesuaian animasi dengan perkembangan siswa dan kemudahan materi terhadap laboratorium virtual yang dikembangkan. 
Metode eksperimen penelitian ini yaitu Quasi Experimental dengan desain eksperimen Nonequivalent Control Group Design. Desain Nonequivalent Control Group Design hampir sama dengan pretest-postest control group-design, hanya saja kelompok eksperimen dan kelompok kontrol tidak dipilih secara random. Pemilihan sampel uji coba dengan menggunakan metode Nonequivalent Control Group Design ini dipilih melalui uji kesetaraan.

Uji yang dilakukan pada tahap evaluasi ini adalah uji keefektifan. Uji ini dilakukan untuk menguji efektifitas produk yang sudah dikembangkan dan melalui tahap revisi sehingga produk yang diujikan sudah layak untuk digunakan. Pada tahap ini peneliti menggunakan dua kelas pada dua sekolah yang berbeda sebagai subjek penelitian. Dua kelas ini akan dibagi menjadi dua, yaitu satu kelas sebagai kelas eksperimen dan satu kelas lainnya menjadi kelas kontrol. Untuk mengukur keefektifan media laboratorium virtual maka dilakukan melalui Uji Independent Sample T-Test.

Uji efektifitas yang ditinjau dari faktor hasil belajar mempunyai tujuan untuk mengetahui sejauh mana media laboratorium virtual yang dikembangkan efektif digunakan dalam peningkatan hasil belajar. Data yang digunakan pada uji efektifitas produk yaitu tes praktik hasil belajar. Produk dinyatakan efektif apabila terdapat perbedaan nilai hasil belajar siswa antara kelas eksperimen dan kelas kontrol. Analisis uji keefektifan produk dilakuakan dengan Uji Independent Sample T-Test. Hipotesis dalam mengambil keputusan uji adalah sebagai berikut:

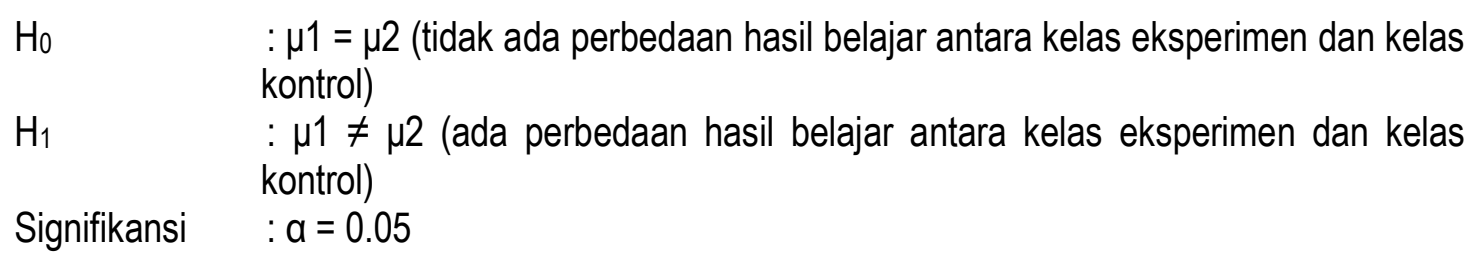

\section{HASIL PENELITIAN DAN PEMBAHASAN}

Pada pembahasan penelitian ini menjelaskan 1) Pengembangan media laboratorium virtual pada praktikum mata pelajaran fisika; 2) Kualitas media laboratorium virtual yang telah dikembangkan dan telah melalui serangkaian uji kelayakan media dan uji coba produk; dan 3) Efektifitas media laboratorium virtual yang digunakan dalam pembelajaran praktikum fisika.

\section{Pengembangan Media Laboratorium Virtual}

Kurangnya peralatan praktikum membuat siswa harus berkelompok dan bergantian dalam melaksanakan praktikum sehingga memerlukan waktu yang lama dalam pembelajaran. Model praktikum berkelompok membuat sebagian siswa dalam kelompok sebagian kurang aktif dalam melaksanakan praktikum dan membutuhkan waktu yang lama dalam pembelajaran. Ketidakmampuan siswa untuk mengeksplorasi beragam bidang fisika akibat kurangnya pasokan peralatan laboratorium dan pengajaran dan pembelajaran yang tidak memuaskan karena bahan yang tersedia sudah usang.

Potensi yang dimliki sekolah dapat digunakan sebagai solusi untuk meningkakan keaktifan siswa dalam melaksanakan praktikum dengan mengembangkan media elektronik. Media elektronik yang diperlukan adalah media yang dapat digunakan oleh masing-masing siswa sehingga siswa dapat lebih aktif dalam pembelajaran dan tidak memakan waktu yang lama dalam pembelajaran. Media yang dikembangkan adalah media laboratorium virtual. Media laboratorium virtual dapat digunakan dalam pembelajaran dengan menggunakan laboratorium komputer di sekolah. Pemilihan media yang tepat akan memberikan dampak yang optimal dalam pemanfaatan media yang digunakan serta siswa menjadi lebih mudah memahami materi yang disajikan. 


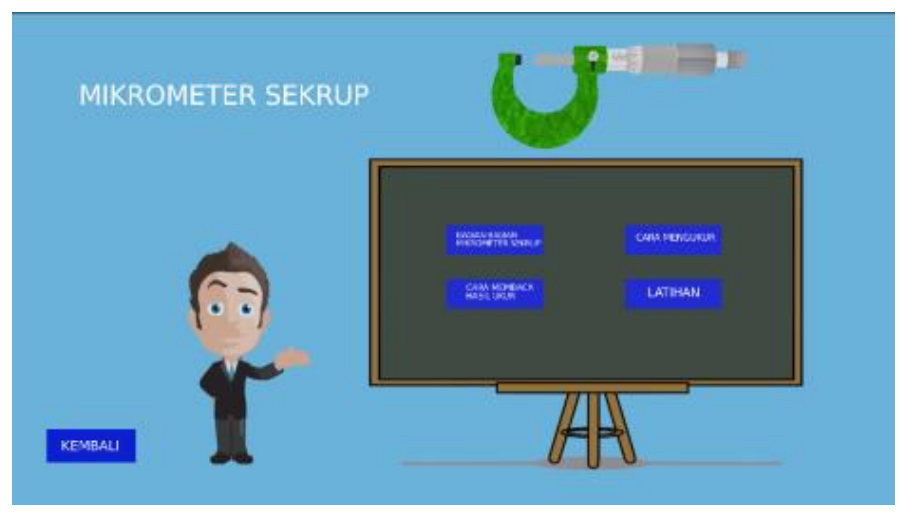

Gambar 1. Tampilan menu mikrometer

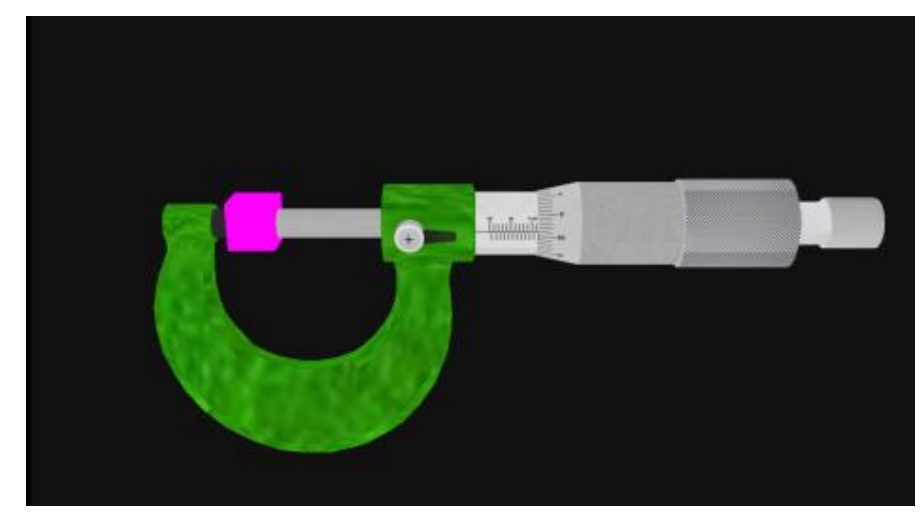

Gambar2. Tampilan cara mengukur dengan mikrometer

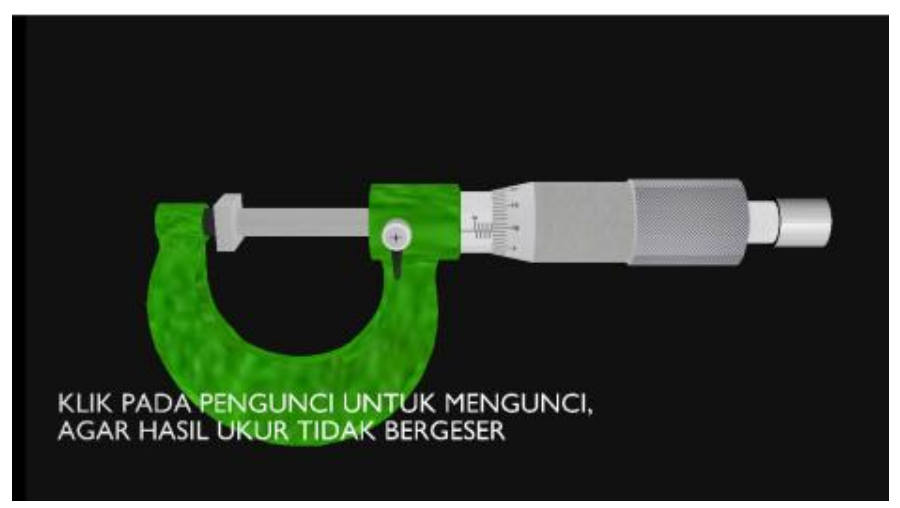

Gambar 3. Tampilan latihan pada mikrometer

\section{Kualitas Media Laboratorium Virtual}

Setelah melalui tahap uji coba, media laboratorium virtual dapat dimanfaatkan dalam pembelajaran. Tahap uji coba tersebut meliputi: 1) uji coba ahli materi; 2) uji coba ahli media; 3) uji coba satu-satu; 4) uji coba kelompok kecil; dan 5) uji coba luas. Pengujian pada ahli materi meliputi pengujian kesesuaian dengan tujuan pembelajaran, kesesuaian materi dengan kurikulum, penyajian materi, penilaian, evaluasi, pendekaatan \& proses belajar. Dari keseluruhan aspek yang diujikan dari ahli materi, rata-rata nilai tiap aspek adalah sebesar 4,52. Hasil tersebut menunjukkan bahwa media yang dikembangkan masuk kategori layak dan sangat baik dari segi materi. 


\section{Efektifitas Media Laboratorium Virtual}

Berdasarkan uji-t dengan menggunakan metode Independent Sample T-Test, pada nilai pre-test kelas eksperimen dan kelas kontrol menunjukan nilai $t$ hitung sebesar 0,523 . Nilai ini lebih kecil dibandingkan dengan nilai t tabel dengan sampel 15, df sebesar 28 dan traf signifikansi 0.05 yaitu sebesar 2.04841. Kesimpulan yang dapat diperoleh adalah tidak ada perbedaan yang signifikan antara nilai pretest kelompok eksperimen dan kelompok kontrol. Hal ini juga dapat diartikan sebagai kelompok eksperimen dan kelompok kontrol sebelum melakukan pembelajaran memiliki kemampuan yang setara.

Kelompok eksperimen dan kelompok kontrol yang telah melakukan pre-test selanjutnya diberikan pembelajaran. Pada kelompok eksperimen, pembelajaran dilakukan dengan menggunakan media laboratorium virtual, sedangkan pada kelompok kontrol, pembelajaran dilakukan dengan menggunakan peralatan biasa. Setelah dilakukan pembelajaran, siswa melakukan post-test. Pos-test ini bertujuan untuk melihat efektifitas media laboratorium virtual pada pembelajaran. Hasil perbandingan nilai pre-test dan post-tes kelompok eksperimen dengan menggunakan uji Paired Samples T-Test diperoleh nilai nilai $t$ hitung sebesar $-6,325$ dengan nilai sig. (2-tailed) 0,000 $<0,05$ sehingga dapat dapat diartikan bahwa terdapat perbedaan rata-rata tes hasil belajar yang signifikan pada kelas eksperimen antara sebelum dan setelah menggunakan media laboratorium virtual.

Efektifitas penggunaan media laboratorium virtual juga dilihat dari perbandingan nilai post-tes kelompok eksperimen dengan nilai post-test kelimpok kontrol dengan uji Independent T-test. Hasil dari uji menunjukan bahwa nilai $p$ value (Sig. (2-tailed)) sebesar 0,039. nilai tersebut lebih kecil dari nilai signifikansi yaitu sebesar 0,05 , sehingga dapat disimpulkan antara data post-test kelompok eksperimen dengan data post-test kelompok kontrol memiliki perbedaan yang signifikan. Kesimpulannya adalah "terdapat perbedaan yang signifikan prestasi belajar antara kelompok siswa yang pembelajarannya menggunakan media laboratorium virtual dengan kelompok siswa yang mengunakan peralatan langsung".

\section{KESIMPULAN}

Berdasarkan hasil penelitian dan pembahasan tentang Pengembangan media Laboratorium Virtua untuk mendukung pembelajaran praktikum fisika dapat disimpulkan sebagai berikut: 1) Penggunaan laboratorium virtual dalam pembelajaran fisika dapat meningkatkan pemahaman siswa tentang materi praktikum yang dilakukan, 2) Laboratorium virtual memiliki efektifitas yang cukup tinngi untuk digunakan dalam pembelajaran sehingga laboratorium virtual dapat menjadi pendamping bahan ajar yang digunakan dalam pembelajaran.

\section{SARAN}

Berdasarkan hasI dari peneliain yang dilakukan, penulis memberikan rekomendasi sebagai berikut: 1) Pelaksanaan praktikum di sekolah terutama pada mata pelajaran fisikan dapat diperkaya dengan menggunakan teknologi, sehingga dapat meningkatkan serta memaksimalkan pembelajaran yang dilakukan. 2) Penggunaan laboratorium virtual dalam pembelajaran hendaknya diawasi atau didampingi oleh guru, sehingga dalam pelaksanaan pembelajaran, siswa dapat terkondisi dengan baik.

\section{DAFTAR PUSTAKA}

Anitah, S. (2008). Media Pembelajaran. Surakarta: UNS Press

Arikunto S. (2006). Dasar-Dasar Evaluasi Pendidikan. Jakarta: Bumi Aksara 
Djamarah \& Syaiful Bahri. (2000). Strategi Belajar Mengajar. Jakarta: Rineka Cipta

Gagne, R. M. \& Briggs, L.J. (1974). Principle of Instructional Design. New york: Holt Rinehart and Winston inc.

Hamalik, O. (2005). Kurikulum dan Pembelajaran. Jakarta: Bumi Aksara

Hartley. (2008). Learning and Studying: A Research Perspective. London: Routledge

Ifeanyi, S. (2012). The Effect of Laboratory Work in Teaching and Learning of Physics in Onitsha North, Anambra State. Journal of Science and Art. 12 (1), 17-84

Illeris, K. (2017). How We Learn: Learning and non-learning in school and beyond. Chennai: Deanta Global Publishing Services

Jaya H. (2012). Pengembangan Laboratorium Virtual untuk Kegiatan Praktikum dan Memfasilitasi Pendidikan Karakter di SMK. Jurnal Pendidikan Vokasi, 2 (1), 81-90

Jenny, N. Y. \& Fai, T. S. (2001). Evaluating the Effectiveness of an Interactive Multimedia ComputerBased Patient Education Program in Cardiac Rehabilitation. The Occupational Therapy Journal of Research, 21 (4), 260-275

Karna S., \& Julin P. (2015). A Framework for Measuring Student and Staff Satisfaction With University Campus Facilities. Quality Assurance in Education, 23 (1), 57-66

Mhlongo, M.R., Kriek, J. \& Basson, I. (2011). The Contribution of Simulations to the Practical Work of Foundation Physics Students at the University of Limpopo. Multicultural Education \& Technology Journal, 5(4), 288-302

Mishra, A., Vijayshri \& Garg, S. (2010). A Preliminary Evaluation of Undergraduate Physics Laboratory Instruction Offered at Ignou. Asian Association of Open Universities Journal 5 ( 2), 56-77

Mulyasa. (2003). Manajemen Berbasis Sekolah. Bandung: PT Remaja Rosdakarya

Nirwana R. R. (2011). Pemanfaatan Laboratorium Virtual dan E-Reference dalam Proses Pembelajaran. Jurnal Phenomenon, 1 (1), 115-123

Kemendikbud. (2016). Kompetensi Inti dan Kompetensi Dasar Pelajaran pada Kurikulum 2013 pada Pendidikan Dasar dan Pendidikan Menengah. Jakarta. Kementerian Pendidikan dan Kebudayaan

Redel-Macíasa, M.D., Pinzib, S., Martínez-Jiménez, M.P., Dorado, G. \& Dorado, M.P. (2016). Virtual laboratory on biomass for energy generation. Journal of Cleaner Production, 112 (5), 3842-3851

Robotham, D. (2003). Learning and training: developing the competent learner. Journal of European Industrial Training, 27(9), 473-480

Sambrook, S. (2001). Factors influencing learners' perceptions of the quality of computer based learning materials. Journal of European Industrial Training, 25 (3).157-167

Serdyukov. (2017). Innovation in education: what works, what doesn't, and what to do about it? Journal of Research in Innovative Teaching \& Learning, 10 (1), 4-33

Simandan, D. (2013). Introduction: Learning as geographical process. The Professional Geographer, 65(3), 363-368

Smaldino S. E., Lowther D. L. \& Russell J. D. (2008). Instructional Technology and Media for Learning. Upper Saddle River, NJ: Pearson

Sprawls, P. (2008). Evolving models for medical physics education and training: a global perspective. Biomedical Imaging and Intervention Journal, 4(1), 1-11 
Sudjana, N. (2007). Dasar-dasar Proses Belajar Mengajar. Bandung: Sinar Baru Algensindo

Sukirman. (2012). Pengembangan Media Pembelajaran. Yogyakarta: PT. Pustaka Insan Madani

UNESCO. (2002). Information and Communication Technologies in Teacher Eduction: a Planning Guide. Paris: Division of Higher Education UNESCO

Usmeldi. (2016). The Development of Research-Based Physics Learning Model With Scientific Approach to Develop Students' Scientific Processing Skill. Jurnal Pendidikan IPA Indonesia, 5 (1), 134-139 